\title{
E-Healthcare for Celiac Disease—A Multicenter Randomized Controlled Trial
}

\author{
Sabine Vriezinga, $\mathrm{MD}, \mathrm{PhD}^{1}$, Annelise Borghorst, $\mathrm{Bsc}^{1}$, Elske van den Akker-van Marle, $\mathrm{PhD}^{2}$, Marc Benninga, $\mathrm{MD}, \mathrm{PhD}^{3}$, \\ Elvira George, $\mathrm{MD}, \mathrm{PhD}^{4}$, Danielle Hendriks, $\mathrm{MD}^{5}$, Erica Hopman, $\mathrm{PhD}^{6}$, Tim de Meij, $\mathrm{MD}, \mathrm{PhD}^{7}$, \\ Andrea van der Meulen-de Jong, MD, $\mathrm{PhD}^{8}$, Hein Putter, $\mathrm{PhD}^{9}$, Edmond Rings, MD, PhD ${ }^{1,10}$, Maaike Schaart, MD, $\mathrm{PhD}^{1}$, \\ Joachim Schweizer, MD, PhD¹, Margot Smit, MD ${ }^{5}$, Merit Tabbers, MD, $\mathrm{PhD}^{3}$, Michel Weijerman, MD, $\mathrm{PhD}^{11}$, \\ Margreet Wessels, $\mathrm{MD}^{1,12}$, and M. Luisa Mearin, $\mathrm{MD}, \mathrm{PhD}^{1}$
}

Objective To evaluate the (cost-)effectiveness of online consultations in follow-up of patients with celiac disease (CD).

Study design Multicenter randomized, controlled trial involving 304 patients aged $\leq 25$ years with CD for $\geq 1$ year, randomized to an online $(n=156)$ or outpatient consultation $(n=148)$. An online consultation included questionnaires for symptom and growth measurement. Antitransglutaminase-type-2 antibodies were determined using a pointof-care (POC) test. Controls had a traditional consultation with antitransglutaminase-type-2 antibodies testing in laboratories. Both groups completed questionnaires concerning CD-specific health-related quality of life (HRQOL), gluten-free diet adherence, and patient satisfaction. Six months later, participants repeated HRQOL and patient satisfaction questionnaires and the POC test. The primary outcome was anti-transglutaminase-type- 2 antibodies after 6 months, and the secondary outcomes were health problems, dietary adherence, HRQOL, patient satisfaction, and costs.

Results The performance of the POC test was inferior to laboratory testing (2/156 positive POC tests vs 13/148 positive laboratory tests; $P=.003$ ). Health problems were detected significantly more frequently using online consultation. The detection of growth problems and dietary transgressions was similar. HRQOL (from 1 [good] to 5 [poor]) improved after online consultation (from 3.25 to $3.16[P=.013$ ] vs controls from 3.10 to $3.23 ; P=.810$ ). Patient satisfaction (from 1 [low] to 10 [high]) was 7.6 (online) vs 8.0 (controls; $P=.001$ ); $58 \%$ wished to continue online consultations. Mean costs per participant during the studied period were $€ 202$ less for the online group $(P<.001)$. Conclusions The primary outcome could not be tested because the POC test was unreliable. Nevertheless, our results indicate that online consultations for children and young adults with CD are cost saving, increase CDspecific HRQOL, and are satisfactory for the majority. (J Pediatr 2018;195:154-60).

Trial Registration Trialregister.nl: NTR3688.

\section{See editorial, p 15}

eliac disease $(\mathrm{CD})$ is an immune-mediated systemic disorder occurring in genetically susceptible individuals and it is elicited by gluten ingestion. ${ }^{1}$

$\mathrm{CD}$ may be considered a public health problem, with a prevalence ranging from $1 \%$ to $3 \%$, which corresponds with about 5 million affected people in the European community. ${ }^{1-3}$ Treatment with a gluten-free diet (GFD) restores the small bowel alterations and improves clinical complaints in the majority of the patients. ${ }^{1,4}$ In The Netherlands, children with CD diagnosed $>1$ year ago are usually followed up annually. ${ }^{5}$ Traditional medical care for patients with $\mathrm{CD}$ consists of regular physician visits to evaluate their health, weight, height (in children), GFD adherence, and CD-specific serum antibodies. ${ }^{5,6}$ Although important, these measures

\footnotetext{
CD Celiac disease

ELISA Enzyme-linked immunosorbent assay

GFD Gluten-free diet

HRQOL Health-related quality of life

POC Point-of-care (test)

TG2A Antitransglutaminase-type-2 antibodies
}

From the ${ }^{1}$ Department of Pediatrics; ${ }^{2}$ Department of Medical Decision Making, Leiden University Medical Center, Leiden; ${ }^{3}$ Departments of Pediatrics, Emma Children's Hospital, Academic Medical Center, Amsterdam; ${ }^{4}$ Medical Centre Alkmaar, Alkmaar; ${ }^{5} J u l i a n a$ Children's Hospital, The Hague; ${ }^{6}$ Department of Dietetics, Leiden University Medical Center, Leiden; ${ }^{7}$ VU University Medical Center, Amsterdam; ${ }^{8}$ Department of

Gastroenterology and Hepatology, Leiden University Medical Center, Leiden; ${ }^{9}$ Department of Medical Statistics, Leiden University Medical Centre, Leiden; ${ }^{10}$ Sophia Children's Hospital, Erasmus Medical Centre, Rotterdam; ${ }^{11}$ Alrijne Hospital, Leiderdorp; and ${ }^{12}$ Rijnstate Hospital, Arnhem, The Netherlands

Funded by the Dutch "Maag Lever Darm Stichting" (WO1198), ZonMW (171201006), and STICOON (Dutch Foundation for Research in Celiac Disease). The point-ofcare tests were provided free of charge by the

manufacturers. The authors declare no conflicts of interest.

0022-3476/\$ - see front matter. ๑ 2017 Elsevier Inc. All rights reserved.

https://doi.org10.1016/j.jpeds.2017.10.027 


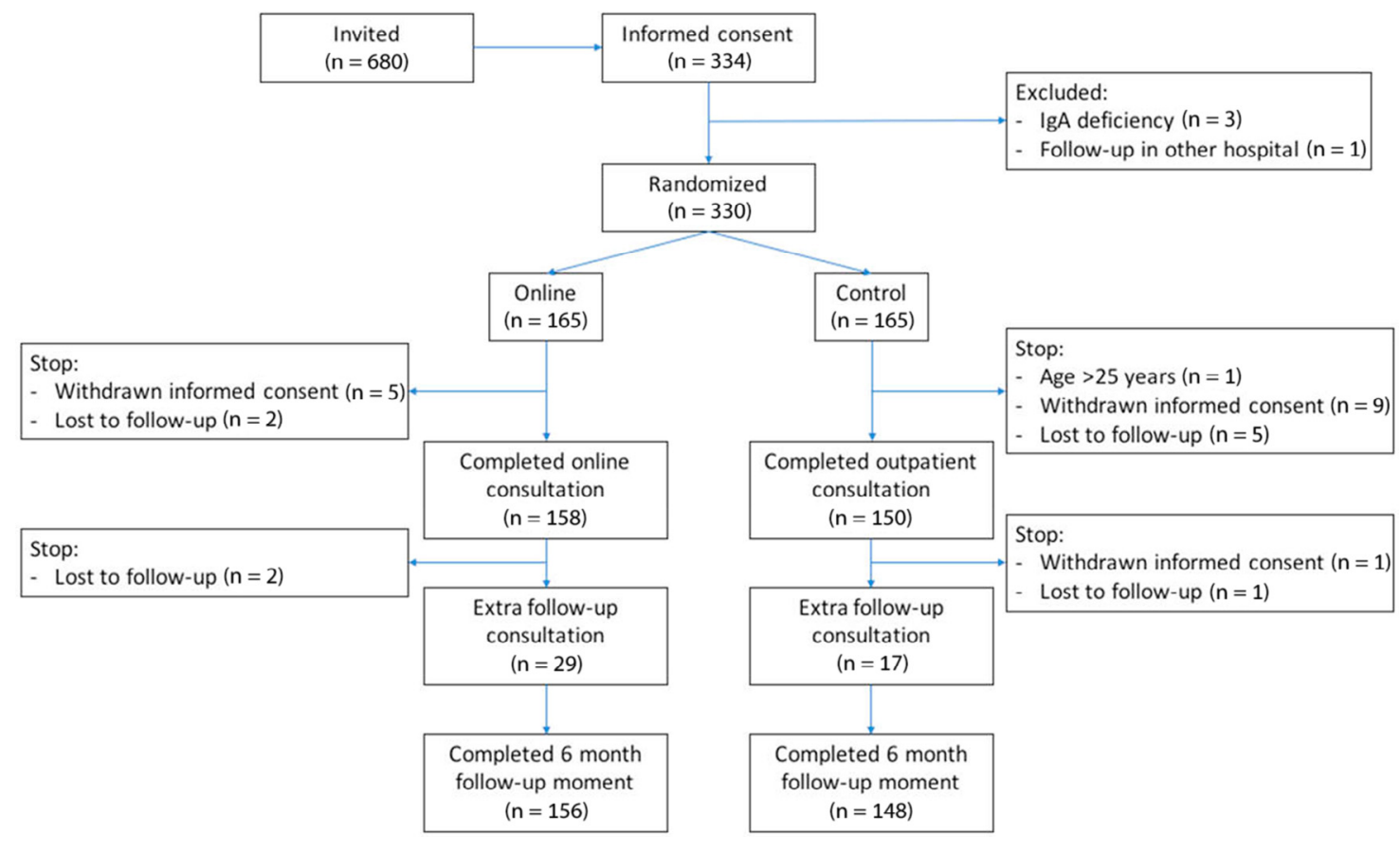

Figure 1. Recruitment, randomization, and follow-up of children and young adults with CD. Four patients did not meet the inclusion criteria and were excluded before randomization. After randomization, 1 participant was excluded for exceeding the age limit (age 25.7 years). During the project, the number of participants decreased to 304 (online $n=156$; control $n=148$ ) because 15 participants withdrew their informed consent and another 10 participants were lost to follow-up.

can be time consuming. Moreover, many patients do not visit their physician for regular CD follow-up. ${ }^{7}$ Time constraints during outpatient follow-up also restrict comprehensive assessments of a patient's health-related quality of life (HRQOL) and dietary adherence. Previous studies in adults with other chronic diseases suggest that online consultations can encourage patients to improve healthcare participation and enable them to deal with symptoms, treatment, physical and psychosocial consequences, and lifestyle changes through successful disease self-management. ${ }^{8,9}$ We developed an online consultation as a substitute for an outpatient consultation in the follow-up of CD in children and young adults (CoelKids). We hypothesized that disease control and participant satisfaction would be similar in patients using an online consultation or traditional outpatient follow-up.

\section{Materials}

For this multicenter, randomized, clinical trial (Trialregister.nl: NTR3688), children and young adults $\leq 25$ years with diagnosed CD for $\geq 1$ year were recruited between May 2012 and July 2014 from 3 academic and 4 nonacademic hospitals in the Netherlands. Exclusion criteria were IgA deficiency, no Internet access, and insufficient comprehension of Dutch language. All authors had access to the study data and had reviewed and approved the final manuscript.

\section{Intervention}

After obtaining written informed consent, participants were randomized to the online or control group, stratified by age at inclusion and sex (Figure 1, Table I). The patients (or parents) in the online group were asked to complete a symptom questionnaire (ie, abdominal pain, appetite, lassitude, and defecation) and instructed to measure height and weight, which were subsequently plotted on their growth charts. ${ }^{11,12}$ For determination of the CD-specific IgA antitransglutaminasetype-2 antibodies (TG2A), the online group was provided (free of charge) with the validated and commercially available pointof-care (POC) test (Biocard Celiac Test, AniBiotech, Vantaa,

Table I. Characteristics of the 304 participants with CD randomized to the online or control group

\begin{tabular}{lcc}
\hline Characteristic & $\begin{array}{c}\text { Online group } \\
(\mathbf{n}=\mathbf{1 5 6})\end{array}$ & $\begin{array}{c}\text { Control group } \\
(\mathbf{n}=\mathbf{1 4 8})\end{array}$ \\
\hline Female, $\mathrm{n}(\%)$ & $107(68.6)$ & $97(65.5)$ \\
Age (y), mean (min-max) & $11.0(2.6-24.1)$ & $11.4(2.1-24.5)$ \\
Age at CD diagnosis (y), mean (min-max) & $4.3(0.9-17.9)$ & $4.9(1.0-23.4)$ \\
Disease duration (y), mean (min-max) & $6.9(1.0-20.3)$ & $6.7(1.0-22.9)$ \\
GFD score, ${ }^{*} \mathrm{n}(\%)$ & & \\
$0-1$ & $12(7.7)$ & $19(12.8)$ \\
2 & $2(1.3)$ & $1(0.7)$ \\
$3-4$ & $142(91.0)$ & $128(86.5)$ \\
\hline
\end{tabular}

*Scores of 0-1 = GFD not followed; 2 = GFD followed but with errors; 3-4 = strict GFD followed. ${ }^{10}$ 
Finland). ${ }^{13-16}$ It requires 1 drop of fresh blood, obtained by finger prick. The result (positive/negative) should be interpreted after 10 minutes in a well-lit place. Written instructions and a video tutorial were provided. Participants e-mailed us a picture of the result and returned the test by mail so that we could check the result. In addition, they completed online questionnaires on GFD adherence, CD-specific HRQOL, and parents' and/ or patients' satisfaction with the consultation. The physicianresearcher discussed the results with the participants/parents over the telephone, and sent a copy of the results to their physician. In case of abnormalities, an outpatient consultation was scheduled.

The control group received traditional care at the outpatient clinic with their own physician. A standardized summary of the consultation's narrative concerning abdominal pain, appetite, lassitude, and defecation was used for data analysis. Weight and height was measured and plotted in the growth chart. Serum TG2A was measured with a conventional enzymelinked immunosorbent assay (ELISA) at all hospital laboratories (Appendix; available at www.jpeds.com). After the consultation, participants completed the questionnaires concerning GFD adherence, CD-specific HRQOL, and patient satisfaction. Their physician was blinded to the outcomes of these questionnaires.

To asses disease control, all participants were asked to measure TG2A at home 6 months after the online or outpatient consultation using the POC test (Figure 1).

The primary outcome was disease control 6 months after the participant had finished the online or outpatient consultation, defined as negative TG2A using the POC test. Secondary outcomes were detection of health problems and dietary adherence as well as CD-specific HRQOL, patient satisfaction, and costs 6 months after the online or outpatient consultation.

\section{Measures}

Abnormal growth was defined as a deviation from the previous measurement of $\geq 1 \mathrm{SD}$ for height/age or weight/height. GFD adherence was assessed using the Dutch adaptation of a previously validated questionnaire. ${ }^{10}$ The score ranged from 0 to $3(0-1=$ GFD not followed; $2=$ GFD followed but with errors; 3 = strict GFD). CD-specific HRQOL was assessed using the validated CDDUX questionnaire, consisting of 12 questions divided into 3 subscales: communication, diet, and having CD (Appendix) ${ }^{17}$ Participants rated their satisfaction with the online or outpatient consultation on a scale of 1-10 (ie, $1=$ lowest; $10=$ highest). In addition, we used a modified version from the Dutch translations of 3 validated satisfaction questionnaires (Tables IV and $\mathbf{V}$ and Appendix). ${ }^{18-20}$ The cost minimization analysis included costs of medical care ${ }^{21}$ (including physician and patient/parent-initiated consultations during the study period) and nonmedical costs (parents' and/ or participants' work absence, travel time/costs; Appendix).

\section{Statistical Analyses}

The study protocol was approved by the medical ethics committee of the Leiden University Medical Center and the respective boards of participating centers. The Appendix includes the calculation of sample size. Participants completed the online questionnaires using a data management application (NEN7510 certified). Randomization was carried out as a stratified, randomly varying block design (Appendix). For comparison of disease control, HRQOL and satisfaction, the $\chi^{2}$, Mann-Whitney $\mathrm{U}$, and Armitage trend tests were used as appropriate. Changes over time within both groups were detected with the McNemar and Wilcoxon signed-rank tests as needed. Generalized estimating equations were used to compare costs between both groups. Analyses were performed using SPSS software (IBM SPSS Statistics for Windows, version 23.0; IBM Corp, Armonk, NY).

\section{Results}

In total, 304 participants were randomized to the online $(\mathrm{n}=156)$ or control $(\mathrm{n}=148)$ groups (Figure 1$)$. The characteristics of the participants were similarly distributed in both groups (Table I). The mean duration between consultation and follow-up was 6.8 months (SD 2.5) in the online group and 7.6 months (SD 3.3) in the controls $(P=.001)$.

Baseline TG2A results were available in 298 of 304 participants (online $\mathrm{n}=153$ measured with the POC test; controls $\mathrm{n}=145$ measured in the hospital laboratory; Figure 2). There were significantly more controls with positive TG2A than online participants: 13 of 145 (mean titer of $21.5 \mathrm{U} / \mathrm{mL}$; range, 8-56) vs 2 of 153 (POC test; $P=.003$ ). In 3 of the 13 controls with a positive TG2A at baseline, TG2A continued to decrease from the time of $\mathrm{CD}$ diagnosis. This change was considered normal. Approximately 6 months later, TG2A was reassessed with the POC test in 279 of 298 participants with available baseline TG2A results (online $\mathrm{n}=148$; control $\mathrm{n}=131$ ). The number of positive POC tests in the online group was similar to baseline $(5 / 148$ vs $2 / 153 ; P=.25)$. In the control group, significantly fewer POC tests were positive than laboratory tests at baseline ( $1 / 134$ vs $13 / 145 ; P=.012)$. The single positive POC test corresponded with a participant with a negative TG2A at baseline $(6 \mathrm{U} / \mathrm{mL})$.

Abdominal pain, lassitude, and increased appetite were reported significantly more frequently by the online group (Table II; available at www.jpeds.com). Detection of growth problems was not statistically different in either group (10 online; 3 controls; $P=.059$; Appendix).

The self-reported dietary adherence was described as "strict" by 142 of 156 online participants and by 128 of 148 controls ( $91 \%$ vs $87 \% ; P=.297$; Table I). Positive TG2A measured with the POC test or by conventional ELISA test did not correlate with self-reported gluten consumption $(K=0.001$ and $\mathrm{K}=-0.024$ respectively).

During baseline consultation, participants' overall CDspecific HRQOL was similar in both groups (neutral to bad; Table III). Upon reassessment approximately 6 months later, a statistically significant improvement was observed in the overall score of the online group $(P=.013)$ but not in the controls $(P=.810)$. The improvement concerned the subscales of Communication and Diet (Table III). 

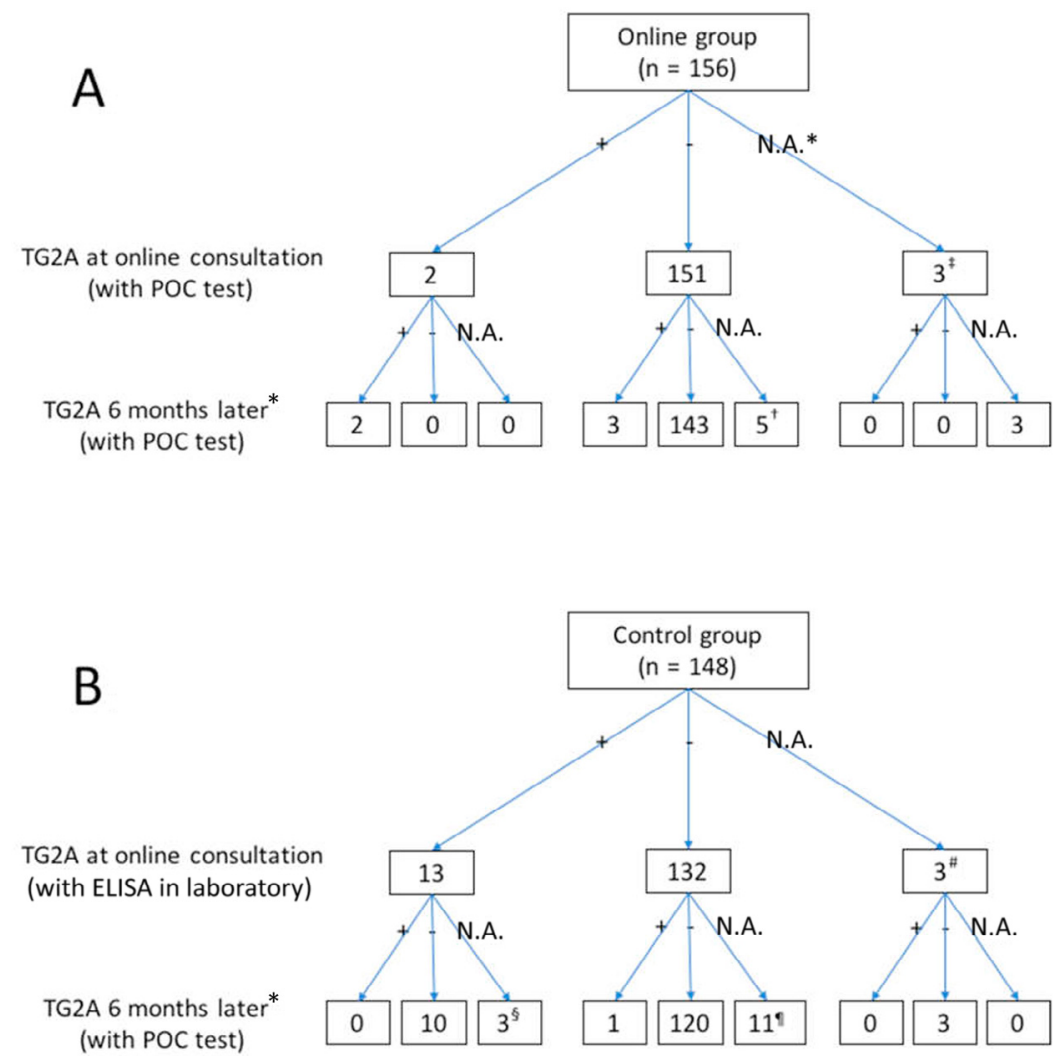

Figure 2. Correlation of $\lg A$ TG2A results in 304 patients with CD randomized to measurement with the POC test (online, $\mathbf{A}$ ) or in hospital laboratory (controls, B) at baseline consultation and approximately 6 months later using the POC test. *At 6.8 months after baseline for E-health group and 7.6 months for controls. Reasons for test results being not available (more than one reason per participant possible): ${ }^{\ddagger}$ Anxiety $(n=2)$; unclear instructions $(n=1)$; not enough blood obtained with finger prick $(n=1) ;{ }^{\dagger}$ Anxiety $(n=3)$; technical failure $(n=1)$; unwilling to repeat test $(n=1)$; *Blood was not withdrawn $(n=2)$; only anti endomysium antibodies were assessed $(n=1)$; ${ }^{\S}$ Anxiety $(n=2)$; unclear instructions and interpretation results $(n=1)$; ${ }^{\natural} A n x i e t y$ $(n=6)$; unclear instructions $(n=3)$; not enough blood obtained with finger prick $(n=2)$; technical failure $(n=1)$; unclear interpretation result $(\mathrm{n}=1)$. NA, Not available.

The mean satisfaction was significantly higher in controls than in the online group both at baseline (mean grade, 8.16 [range, 5-10] vs 7.65 [range, 2-10]; $P<.001$ ) as well as 6 months later (mean grade, 8.01 [range, $4-10$ ] vs 7.58 [range, 3-10]; $P=.001$; Appendix). However, $48 \%$ of the online participants $(n=75)$ regarded the online consultation to be as good as outpatient care (disagree $n=47$; not agree or disagree $n=34$ ). In fact, $58 \%$ of them $(n=90)$ wished to continue with the online consultations (disagree $\mathrm{n}=32$; not agree or disagree $\mathrm{n}=34$; Table V). Six months after the intervention, the POC test was preferred to the conventional venipuncture by $80 \%$ of the online participants and by $81 \%$ of the controls (Table VI; available at www.jpeds.com).

Extra follow-up consultations because of detected abnormalities at the baseline consultation were similarly required among the online $(n=29)$ and the control $(n=17)$ groups $(P=.06$; Figure 1 and Appendix).

The mean costs in the online group were €93 lower than in the controls (total costs $€ 143$ vs $€ 236$; $P<.001$; Table VII; available at www.jpeds.com). The nonmedical costs for the online consultation were $€ 64$ lower than those of the outpatient consultation $(P<.001)$. The medical costs of the consultations (including follow-up visits during the study period) were not different $(P<.096)$. For this calculation, only the TG2A testing in laboratory ( $€ 15.10)$ determines the costs of blood work in the controls. However, when taking into account the complete blood work, which is usually performed during the outpatient consultation in the Netherlands (on average $€ 124$ per consultation; SD $€ 58$, Appendix), the medical costs of the online consultation were significantly lower than of an outpatient consultation ( $€ 130$ vs $€ 268 ; P<.001$ ) and the mean total costs in the online group were $€ 202$ lower per participant during the study period (medical savings of $€ 138$; nonmedical savings of €64).

\section{Discussion}

Because the performance of the POC test was unreliable, we could not test our primary outcome. Despite this, our results indicate that online consultations for children and young adults 


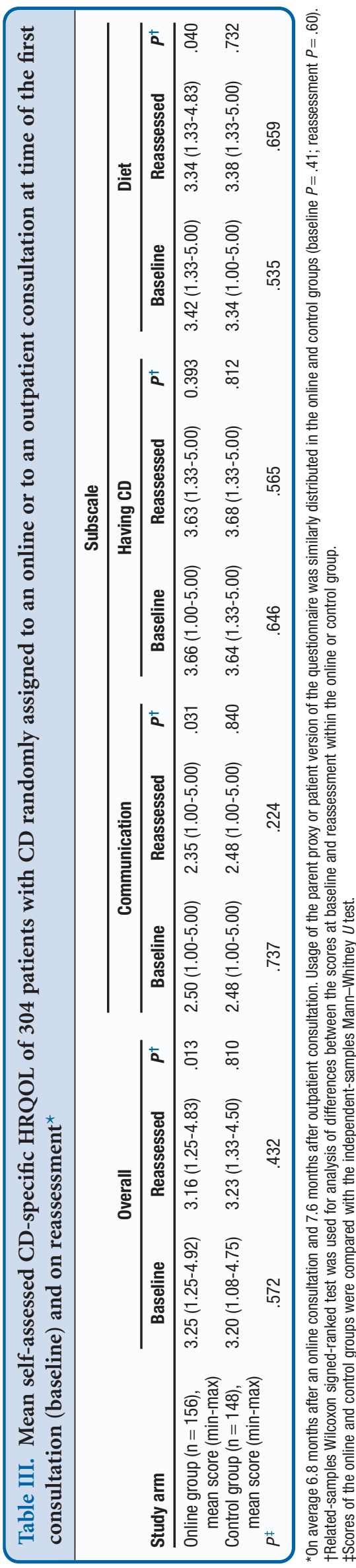

with CD save costs, increase CD-specific HRQOL, and are satisfactory for the majority of participants.

When this study commenced in 2011, the performance of POC self-tests for monitoring treated CD had not yet been evaluated prospectively. The results of later studies on POC tests other than those used in our study showed sensitivities of $63 \%$ and $84 \%$ in treated $\mathrm{CD}^{22,23}$ The false-negative POC tests concerned samples with antibody titers near the cutoff of normality. ${ }^{22,23}$ Because these low titers are expected in patients with $\mathrm{CD}$ occasionally making dietary transgressions, this group requires a very sensitive POC self-test. In a recent, unpublished study from our research group, we identified a different POC test that is suitable for follow-up of patients with treated CD (Appendix).

A previous online intervention successfully achieved increased GFD adherence and knowledge in Australian patients with $\mathrm{CD} .{ }^{24}$ We evaluated online consultations for $\mathrm{CD}$ control, taking into account the participant's physical condition, CD-specific HRQOL, satisfaction, and providing a cost analysis. Our results show that the online consultation detects symptoms significantly more often than traditional care, and it increases the CD-specific HRQOL while saving costs. The vast majority of the participants favored a POC self-test rather than the conventional venipuncture (80\%), implying that they would welcome its implementation in their healthcare. The lack of correlation between TG2A results and self-reported dietary adherence are in agreement with previous reports (Appendix), suggesting that patient interviews are better to evaluate compliance. ${ }^{5}$

The online participants reported significantly more abdominal pain and lassitude than the controls (and their parents) during the outpatient consultation. It is unlikely that such difference occurred by chance, but may be partly explained by different methods to assess symptoms in both groups. The online group filled in a multiple choice questionnaire and the controls responded to the physician's verbal questioning. It has been reported that pediatricians tend to listen more to the parents than the child. ${ }^{25}$ In our study, parents accompanied all the (pediatric) controls during outpatient clinic visits. In the online group, however, $36 \%$ of the parents specifically indicated that they had completed the consultation together with the child. These parents described that the online consultation frequently initiated a conversation in which their children told them about symptoms parents were not always aware of. Furthermore, $8 \%$ of the children had completed the online consultation without their parents. In contrast, it is possible that the occurrence of more abdominal pain and lassitude in the online group was not always clinically relevant, because these symptoms are more subjective than defecation and appetite.

The improvement in CD-specific HRQOL observed after the online consultation is consistent with the previously described positive effect on patients' coping strategies in relation to their chronic disease. ${ }^{8,9}$ Participant satisfaction with the online consultation in our cohort was not associated with age or disease duration, indicating that the optimal combination of online and outpatient care will be different for every patient, setting an example of personalized medicine. ${ }^{26,27}$ Medical and 
nonmedical costs of the online consultation were significantly lower than of traditional healthcare, which is more conclusive than in studies on other chronic diseases. ${ }^{8,28-30}$ The costs of the POC test we identified as more suitable for use in the follow-up of patients with treated CD are similar to those of the POC test used in the present study, making the cost analysis valid for a setting in which this other test would be used for the at-home measurement of TG2A. We found that costs for healthcare use after online consultations were not increased when compared with controls (Table VII). It may be argued that the costs of the development and maintenance of the information and communication technology system for the online consultation should have been included in our analysis. ${ }^{29}$ However; these costs should be distributed over a larger group of users and a longer time period. Moreover, our online consultation is not designed to supplement, but to substitute, for the traditional outpatient consultation. By showing that the online consultation for $\mathrm{CD}$ follow-up is cost saving, our results suggest the feasibility of its implementation as a part of regular healthcare for patients with CD, thereby supporting its reimbursement by the healthcare system.

Strengths of our study include its randomized design and multicenter setting, including academic and nonacademic hospitals. HRQOL, dietary adherence, and satisfaction were assessed using validated questionnaires. In addition, we did not only consider the expenses incurred by the healthcare sector, but also those of the participants. CD guidelines recommend regular testing for anemia, calcium, folic acid, and vitamins $\mathrm{D}$ and $\mathrm{B}_{12}$ levels. ${ }^{1,5,31-33}$ One may argue that these measures were not evaluated in the E-health consultation. However, it has been shown that in children complementary blood investigations are relevant at the time of diagnosis of CD but have little diagnostic yield during follow-up visits once the patient is placed on a GFD. ${ }^{34}$

Patients who chose to participate in our study may have had a positive attitude toward online care. This factor could influence the generalizability of our results. Because we did not inquire about patients' reasons for refusal (51\%), we remain unaware of their attitude toward online care. In contrast, comparing our participation (49\%) and dropout rates (8\%) with other studies evaluating online consultations in chronic diseases (participation rates of $13 \%-42 \%$; attrition rates of $12 \%$ $37 \%$ ), our study's recruitment and follow-up were quite successful. ${ }^{33,35-37}$ It would have been interesting to compare the number of dropouts with the number of missed and/or cancelled appointments before commencing the study. However, we did not ask for patients' informed consent to collect these data. Moreover, the lower percentage of dropouts in the online group than in the controls ( $6 \%$ vs $11 \%$ ) indicates a better acceptance of online consultations by patients with $\mathrm{CD}$ than in patients with other gastrointestinal diseases. ${ }^{38}$

In conclusion, our study shows that E-healthcare with online consultations for children and young adults with $\mathrm{CD}$ is satisfactory and cost saving, and increases CD-specific HRQOL. In addition, we show that different POC tests have different sensitivities when used in the follow-up of treated CD. Therefore, when implementing online consultations for CD control, it is necessary to use a POC test that has been validated in this specific patient group. We do not advise to completely replace outpatient consultations by online consultations, but suggest that the physician and patient together decide on a personal schedule where online and outpatient consultations alternate.

We are grateful to all the patients and their parents for their efforts to take part in the CoelKids study. We acknowledge the support of Danielle Weinchard and Heleen Voogt, research nurses at Leiden University Medical Centre and Academic Medical Centre, respectively; Anneloes Boers, Nora Farih, Bram van der Geest, Kristel van Roessel, and Rama Wahab, medical students who have worked on the CoelKids study; the nursing staff at the outpatient clinic of Leiden University Medical Center; Rogier van der Velde, Architect medical research data management at Leiden University Medical Centre; the manufacturers of the 3 pointof-care tests used in this study; and Dr Dennise C. Amado, visiting pediatrician at Leiden University Medical Centre, for English language editing.

Submitted for publication Jun 26, 2017; last revision received Sep 28, 2017; accepted Oct 12, 2017

Reprint requests: M. Luisa Mearin, MD, PhD, Leiden University Medical Centre, Department of Pediatrics, J6-S-208, Albinusdreef 2, 2333 ZA Leiden, The Netherlands. E-mail: m.I.mearin_manrique@lumc.nl

\section{References}

1. Husby S, Koletzko S, Korponay-Szabo IR, Mearin ML, Phillips A, Shamir R, et al. European Society for Pediatric Gastroenterology, Hepatology, and Nutrition guidelines for the diagnosis of coeliac disease. J Pediatr Gastroenterol Nutr 2012;54:136-60.

2. Myleus A, Ivarsson A, Webb C, Danielsson L, Hernell O, Högberg L, et al. Celiac disease revealed in 3\% of Swedish 12-year-olds born during an epidemic. J Pediatr Gastroenterol Nutr 2009;170-6.

3. Catassi C, Gatti S, Fasano A. The new epidemiology of celiac disease. J Pediatr Gastroenterol Nutr 2014;(Suppl 1):S7-9.

4. Vriezinga SL, Schweizer JJ, Koning F, Mearin ML. Coeliac disease and gluten-related disorders in childhood. Nat Rev Gastroenterol Hepatol 2015;527-36.

5. Richtlijn Coeliakie en Dermatitis Herpetiformis. Richtlijn Coeliakie en Dermatitis Herpetiformis. Haarlem, The Netherlands: Nederlandse Vereniging voor Maag-Darm-Leverartsen; 2008.

6. Rubio-Tapia A, Hill ID, Kelly CP, Calderwood AH, Murray JA, American College of Gastroenterology. ACG clinical guidelines: diagnosis and management of celiac disease. Am J Gastroenterol 2013;656-76.

7. Bebb JR, Lawson A, Knight T, Long RG. Long-term follow-up of coeliac disease-what do coeliac patients want? Aliment Pharmacol Ther 2006;82731.

8. Wildevuur SE, Simonse LW. Information and communication technologyenabled person-centered care for the "big five" chronic conditions: scoping review. J Med Internet Res 2015;e77.

9. Barlow J, Wright C, Sheasby J, Turner A, Hainsworth J. Self-management approaches for people with chronic conditions: a review. Patient Educ Couns 2002;177-87.

10. Biagi F, Andrealli A, Bianchi PI, Marchese A, Klersy C, Corazza GR. A gluten-free diet score to evaluate dietary compliance in patients with coeliac disease. Br J Nutr 2009;882-7.

11. Alemzadeh N, Rekers-Mombarg LT, Mearin ML, Wit JM, Lamers CB, van Hogezand RA. Adult height in patients with early onset of Crohn's disease. Gut 2002;26-9.

12. Talma H, Schönbeck $Y$, Bakker B, HiraSing RA, van Buuren $S$, Groeidiagrammen 2010. Handleiding bij het meten en wegen van kinderen en het invullen van groeidiagrammen. Leiden: TNO Kwaliteit van Leven; 2010.

13. Raivio T, Korponay-Szabo IR, Paajanen T, Ashorn M, Iltanen S, Collin $\mathrm{P}$, et al. Comparison of a novel whole blood transglutaminase-based ELISA 
with a whole blood rapid antibody test and established conventional serological celiac disease assays. J Pediatr Gastroenterol Nutr 2008;5627.

14. Raivio T, Kaukinen K, Nemes E, Laurila K, Collin P, Kovács JB, et al. Self transglutaminase-based rapid coeliac disease antibody detection by a lateral flow method. Aliment Pharmacol Ther 2006;-:147-54.

15. Nemec G, Ventura A, Stefano M, Di Leo G, Baldas V, Tommasini A, et al. Looking for celiac disease: diagnostic accuracy of two rapid commercial assays. Am J Gastroenterol 2006;1597-600.

16. Korponay-Szabo IR, Raivio T, Laurila K, Opre J, Király R, Kovács JB, et al. Coeliac disease case finding and diet monitoring by point-of-care testing. Aliment Pharmacol Ther 2005;729-37.

17. van Doorn RK, Winkler LM, Zwinderman KH, Mearin ML, Koopman HM. CDDUX: a disease-specific health-related quality-of-life questionnaire for children with celiac disease. J Pediatr Gastroenterol Nutr 2008;14752.

18. Bakken S, Grullon-Figueroa L, Izquierdo R, Lee NJ, Morin P, Palmas W, et al. Development, validation, and use of English and Spanish versions of the telemedicine satisfaction and usefulness questionnaire. J Am Med Inform Assoc 2006;660-7

19. Dick PT, Filler R, Pavan A. Participant satisfaction and comfort with multidisciplinary pediatric telemedicine consultations. J Pediatr Surg 1999;13741.

20. Myers KM, Valentine JM, Melzer SM. Child and adolescent telepsychiatry: utilization and satisfaction. Telemed J E Health 2008;131-7.

21. Hakkaart-van Roijen L, Tan SS, Bouwmans CAM. Handleiding voor kostenonderzoek, methoden en standaard kostprijzen voor economische evaluaties in de gezondheidszorg. Geactualiseerde versie. Institute for Medical Technology Assessment, Erasmus University. Rotterdam, The Netherlands; 2010.

22. Benkebil F, Combescure C, Anghel SI, Besson Duvanel C, Schäppi MG. Diagnostic accuracy of a new point-of-care screening assay for celiac disease. World J Gastroenterol 2013;5111-7.

23. Zanchi C, Ventura A, Martelossi S, Di Leo G, Di Toro N, Not T. Rapid anti-transglutaminase assay and patient interview for monitoring dietary compliance in celiac disease. Scand J Gastroenterol 2013;764-6.

24. Sainsbury K, Mullan B, Sharpe L. A randomized controlled trial of an online intervention to improve gluten-free diet adherence in celiac disease. Am J Gastroenterol 2013;811-7.

25. Tates K, Elbers E, Meeuwesen L, Bensing J. Doctor-parent-child relationships: a 'pas de trois. Patient Educ Couns 2002;5-14.

26. Bos-Touwen I, Schuurmans M, Monninkhof EM, Korpershoek Y, Spruit-Bentvelzen L, Ertugrul-van der Graaf I, et al. Patient and disease characteristics associated with activation for self-management in patients with diabetes, chronic obstructive pulmonary disease, chronic heart failure and chronic renal disease: a cross-sectional survey study. PLoS ONE 2015;e0126400.

27. Duplaga M. The acceptance of e-health solutions among patients with chronic respiratory conditions. Telemed J E Health 2013;683-91.

28. Boyne JJ, Van Asselt AD, Gorgels AP, Steuten LM, De Weerd G, Kragten J, et al. Cost-effectiveness analysis of telemonitoring versus usual care in patients with heart failure: the TEHAF-study. J Telemed Telecare 2013;2428.

29. Grey M, Liberti L, Whittemore R. Costs of development and maintenance of an Internet program for teens with Type 1 diabetes. Health Technol (Berl) 2015;127-33.

30. Pare G, Sicotte C, St-Jules D, Gauthier R. Cost-minimization analysis of a telehomecare program for patients with chronic obstructive pulmonary disease. Telemed J E Health 2006;114-21.

31. National Institutes of Health (NIH). National Institutes of Health Consensus Development Conference Statement on Celiac Disease, June 2830, 2004. Gastroenterology 2005;S1-9.

32. Hill ID, Dirks MH, Liptak GS, Colletti RB, Fasano A, Guandalini S, et al. Guideline for the diagnosis and treatment of celiac disease in children: recommendations of the North American Society for Pediatric Gastroenterology, Hepatology and Nutrition. J Pediatr Gastroenterol Nutr 2005;119.

33. Murch S, Jenkins H, Auth M, Bremner R, Butt A, France S, et al. Joint BSPGHAN and Coeliac UK guidelines for the diagnosis and management of coeliac disease in children. Arch Dis Child 2013;806-11.

34. Wessels MM, van Veen II, Vriezinga SL, Putter H, Rings EH, Mearin ML. Complementary serologic investigations in children with celiac disease is unnecessary during follow-up. J Pediatr 2016;55-60.

35. Balkhi AM, Reid AM, Westen SC, Olsen B, Janicke DM, Geffken GR. Telehealth interventions to reduce management complications in type 1 diabetes: a review. World J Diabetes 2015;371-9.

36. Rikkers-Mutsaerts ER, Winters AE, Bakker MJ, van Stel HF, van der Meer $\mathrm{V}$, de Jongste JC, et al. Internet-based self-management compared with usual care in adolescents with asthma: a randomized controlled trial. Pediatr Pulmonol 2012;1170-9.

37. Voncken-Brewster V, Tange H, de Vries H, Nagykaldi Z, Winkens B, van der Weijden T, et al. A randomized controlled trial evaluating the effectiveness of a web-based, computer-tailored self-management intervention for people with or at risk for COPD. Int J Chron Obstruct Pulmon Dis 2015;1061-73.

38. Knowles SR, Mikocka-Walus A. Utilization and efficacy of internetbased eHealth technology in gastroenterology: a systematic review. Scand J Gastroenterol 2014;387-408. 


\section{Appendix}

\section{Supplementary Methods}

Measurement of TG2A in Laboratory. All participating hospital laboratories used the EliA Celikey for IgA TG2A (ThermoFisher Scientific, Freiburg, Germany). For this test, $<7 \mathrm{U} / \mathrm{mL}$ were considered negative, and $\geq 7 \mathrm{U} / \mathrm{mL}$ were considered positive (range, 0.1 to $\geq 128.0 \mathrm{U} / \mathrm{mL}$ ).

CD-Specific HRQOL. CD-specific HRQOL was assessed using the validated CDDUX questionnaire, consisting of 12 questions divided into 3 subscales: communication, diet, and having CD. ${ }^{1}$ The response options were depicted on a 5-point Likert scale (from 1 [very good] to 5 [very bad]). Parents and participants were free to use either the CDDUX patient's version or the parent-proxy version. The scores for each subscale and the mean overall score were calculated.

Patient Satisfaction Questionnaires. To assess patient satisfaction, we used items applicable to the study situation from the Dutch translations of the validated Ware's Patient Satisfaction Questionnaire III (18 items), Telemedicine Satisfaction and Usefulness Questionnaire (1 item), Parent Satisfaction Survey (3 items), and from a study by Dick et al (2 items)..$^{2-4}$ Items were slightly modified to specifically address online or outpatient consultations. Responses were given on a 5-point Likert scale (from 1 [strongly disagree] to 5 [strongly agree]).

Cost Minimization Analysis. The cost of a resource was valued using standard prices established by the Dutch Healthcare Authority (laboratory determinations) and by Hakkaart et al (personnel costs). ${ }^{5}$ Shipping costs for the online group's equipment were also included. The time spent by the physician during regular consultations, and by the physician-researcher during online consultations, was measured prospectively. Participants also kept track of consultation times.

Sample Size Calculation. Assuming that an increase in inadequate disease control (positive TG2A) from 20\% to $33 \%$ (equivalence margin 13\%) is acceptable in the care of patients with CD, 298 patients needed to be evaluated with a 1 -sided alpha of 0.05 and a power of $80 \%$. Taking into account a $7.5 \%$ loss to follow-up, 316 patients had to be enrolled.

Randomization. Randomization was carried out as a stratified, randomly varying block design (each block size randomly chosen to contain 4-6 allocations). The tables were pregenerated internally within the secure data management system using the following variables as stratification factors: age at inclusion and gender. The random group allocation was divided over 2 groups (online or control group) and the order of the groups was determined by the random number generator of an SQL server. Upon randomization of a new case, the next available record was chosen within the combination of stratification factors to which the case belonged, the identity of the case being randomized stored within the table, and a pointer to the randomization record stored within the data management system. Exact date and time of randomization is stored within the randomization tables and the allocated treatment was stored in the database system.

\section{Supplementary Results}

Growth Problems. Abnormal growth (weight/height deviated $\geq 1 \mathrm{SD}$ ) was found in 4 online participants and 2 controls. Other growth problems were detected in 6 online participants: $-2 \mathrm{SD}$ weight/height growth with a deviation of $0.5 \mathrm{SD}(\mathrm{n}=3) ;-2 \mathrm{SD}$ height/age without catchup growth after CD diagnosis $(n=2)$, obesity $(n=1)$, and in 1 control, an acceleration in height/age of $>2$ SD.

Patient Satisfaction. Responses to satisfaction with the consultation (grade 1-10) were available in all online participants, in 146 of 148 controls at baseline, and in 147 of 148 controls 6 months later. The mean satisfaction was significantly higher in controls than in the online group at baseline (mean grade, 8.16 [range, $5-10$ ] vs 7.65 [range, $2-10$ ]; $P<.001$ ) as well as 6 months later (mean grade, 8.01 [range, $4-10$ ] vs 7.58 [range, 3-10]; $P=.001$ ). Participant baseline satisfaction and 6 months later remained uninfluenced by age (Spearman's rho online, $P=.362$ and $P=.635$; controls, $P=.666$ and $P=.831$ ) or duration of CD (Spearman's rho online, $P=.887$ and $P=.290$; controls, $P=.270$ and $P=.437$ ). In comparison with online participants, the controls agreed more often that everything necessary to provide complete medical care was available. They also reported more often that they felt free to discuss anything they found important, whereas the online group thought that the consultation was more impersonal $(P<.001$; Table IV). In contrast, online participants found the timing and location of the consultation to be more convenient than did the controls $(P=.018$ and $P=.001$, respectively; Table IV). Furthermore, $48 \%$ of the online group $(n=75)$ regarded the online consultation to be as good as outpatient care (disagree $n=47$; not agree or disagree $n=34$ ). In fact, $58 \%(n=90)$ wanted to continue with online consultations ( disagree $\mathrm{n}=32$; not agree or disagree $\mathrm{n}=34$; Table $\mathrm{V}$ ). A traditional consultation was preferred by $41 \%$ of the online group $(\mathrm{n}=64$; disagree $\mathrm{n}=61$; not agree or disagree $\mathrm{n}=31$ ). Technical problems were experienced by $31 \%(n=48$; no problems $\mathrm{n}=91$; no opinion $\mathrm{n}=17$; Table $\mathrm{V}$ ). The POC self-test was preferred to the conventional venipuncture by $80 \%$ of the online participants and $81 \%$ of the controls (Table VI). A conventional venipuncture was preferred because of a nurse's expertise, hospital environment, or the possibility of doing additional blood tests (Table VI).

Reasons for Extra Follow-Up Consultations. For 29 online participants and 17 controls, abnormalities were detected and further investigated during an extra follow-up consultation $(P=.061)$. This visit was because of CD-related symptoms in 6 online participants and 2 controls, and growth problems in 10 online participants ( 1 also had symptoms) and 3 controls. The 2 online participants with a positive POC self-test and the 
3 participants with unsuccessful self-tests were referred to the hospital for assessment of serum TG2A. Positive serum TG2A was confirmed in 1 participant with a positive POC self-test. The other participant was already known to have positive serum TG2A and did not give consent for reassessment. Of the 10 controls with abnormal TG2A, 7 were referred to a dietician for dietary assessment. In the other 3 participants, TG2A was only slightly positive $(8-11 \mathrm{U} / \mathrm{mL})$ and expectant management was provided. A consultation with a dietician and/or physician was scheduled for 3 of the 6 online participants with self-assessed nonadherence. The other 3 participants declined the offer. In the control group, 3 patients were referred to a dietician because of physician-assessed nonadherence to the GFD ( 2 of them also had positive TG2A). Furthermore, 3 online participants with a previously low vitamin D or folic acid level or previously high thyroidstimulating hormone and antithyroid peroxidase antibodies were referred to the outpatient clinic. In the same online group, a gluten challenge was requested by 2 participants (parents doubted the diagnosis) and 1 participant was referred to the outpatient clinic because of premature pubarche. Furthermore, additional follow-up consultations were scheduled in 4 controls: slightly positive anti-endomysium antibodies despite negative TG2A $(\mathrm{n}=1)$, failure of TG2A determination $(\mathrm{n}=1)$, repeating iron determination $(\mathrm{n}=1)$, and a consultation with a social worker $(n=1)$. In addition, 6 online participants had an additional follow-up consultation because of dissatisfaction with the POC self-test $(n=5)$ or the online consultation $(\mathrm{n}=1)$.

Costs. Complete blood counts and others tests (eg, folic acid, vitamin $\mathrm{B}_{12}$, calcium, alkaline phosphatase, and iron status), were also determined in the outpatient group, as recommended by the Dutch evidence-based CD guidelines. ${ }^{6}$

\section{Supplementary Discussion}

Comparative Study with Three Different POC Tests. Three different POC tests were performed on 142 blood samples from a different CD population (all IgA competent, treated with a GFD, and aged $\leq 18$ years) who attended the pediatric gastroenterology outpatient clinic of Leiden University Medical Center. The study ran from March 28, 2014, to August 18, 2015. Patients were included if all inclusion criteria were met: 1 ) CD diagnosed according to the guidelines of the European Society of Pediatric Gastroenterology Hepatology and Nutrition, ${ }^{7}$ 2) GFD initiated before POC testing, and 3) TG2A determined at the hospital laboratory as part of standard care. ${ }^{6}$ Information about a patient's sex, age, and disease duration was obtained. All identifying details were encoded. The following POC tests were used:

Test A: Ani-Biotech, Biocard Celiac Test for IgA TG2A (AniBiotech, Vantaa, Finland);

Test B: BIOHIT, Celiac quick test for IgA, IgG, and IgM TG2A (Biohit Oyj, Helsinki, Finland); and

Test C: Eurospiral, Xeliac Test Professional for IgA and IgG TG2A (Eurospital SpA, Trieste, Italy).
Results of the POC tests were evaluated after 10 and 30 minutes and 1 day, blinded to the outcome of the ELISA test. Good performance of the POC test was defined as sensitivity $\geq 90 \%$ (95\% CI excludes values of $<90 \%$ ). Table VIII shows that test B had a good performance, significantly better than $\mathrm{A}$ and $\mathrm{C}$ at all evaluated time points, and that it is suitable for E-healthcare in follow-up for CD.

Proxy Assessment of Complaints. In a study among asthmatic children, there was a large discrepancy between physician assessment and the child's description of disease control. ${ }^{8}$ In $42 \%$ of the children who described their asthma as uncontrolled, physicians assessed the asthma to be well-controlled, just as $73 \%$ of the parents reported good control, whereas their children disagreed. ${ }^{8}$

GFD Adherence and TG2A Results. The lack of a correlation between TG2A results and self-reported dietary adherence are in agreement with previous reports: in a group of 15 adult patients with CD from the Netherlands ( 9 untreated, 6 making dietary transgressions), only 1 patient had a positive serum IgA TG2A. ${ }^{9}$ Moreover, serum TG2A was positive in $<50 \%$ of a group of Italian patients who reported dietary transgressions. ${ }^{9}$

Motivation for Online Consultations. It may be hypothesized that, in our cohort, young adults who have been diagnosed earlier would use the online consultation with ease to manage their disease, whereas those who were recently diagnosed (or their parents) would be less enthusiastic. However, these factors were not associated with participant satisfaction. Information about other factors that may have been associated with patient motivation for online consultations, such as (parental) educational level or place of residence, was unavailable in our study. ${ }^{10,11}$

\section{References}

1. van Doorn RK, Winkler LM, Zwinderman KH, Mearin ML, Koopman HM. CDDUX: a disease-specific health-related quality-of-life questionnaire for children with celiac disease. J Pediatr Gastroenterol Nutr 2008;47:147-52.

2. Bakken S, Grullon-Figueroa L, Izquierdo R, Lee NJ, Morin P, Palmas W, et al. Development, validation, and use of English and Spanish versions of the telemedicine satisfaction and usefulness questionnaire. J Am Med Inform Assoc 2006;13:660-7.

3. Dick PT, Filler R, Pavan A. Participant satisfaction and comfort with multidisciplinary pediatric telemedicine consultations. J Pediatr Surg 1999;34:137-41.

4. Myers KM, Valentine JM, Melzer SM. Child and adolescent telepsychiatry: utilization and satisfaction. Telemed J E Health 2008;14:131-7.

5. Hakkaart-van Roijen L, Tan SS, Bouwmans CAM. Handleiding voor kostenonderzoek, methoden en standaard kostprijzen voor economische evaluaties in de gezondheidszorg. Geactualiseerde versie. Diemen: College voor Zorgverzekeringen; 2010.

6. Richtlijn Coeliakie en Dermatitis Herpetiformis. Richtlijn Coeliakie en Dermatitis Herpetiformis. Haarlem: Nederlandse Vereniging voor MaagDarm-Leverartsen; 2008.

7. Husby S, Koletzko S, Korponay-Szabo IR, Mearin ML, Phillips A, Shamir R, et al. European Society for Pediatric Gastroenterology, Hepatology, and 
Nutrition guidelines for the diagnosis of coeliac disease. J Pediatr Gastroenterol Nutr 2012;54:136-60.

8. Shefer G, Donchin M, Manor O, Levy-Hevroni R, Schechter A, Cohen $\mathrm{R}$, et al. Disparities in assessments of asthma control between children, parents, and physicians. Pediatr Pulmonol 2014;49:943-51.

9. Hopman EG, von Blomberg ME, Batstra MR, Morreau H, Dekker FW, Koning F, et al. Gluten tolerance in adult patients with celiac disease 20 years after diagnosis? Eur J Gastroenterol Hepatol 2008;20:423-9.

10. Bos-Touwen I, Schuurmans M, Monninkhof EM, Korpershoek Y, SpruitBentvelzen L, Ertugrul-van der Graaf I, et al. Patient and disease characteristics associated with activation for self-management in patients with diabetes, chronic obstructive pulmonary disease, chronic heart failure and chronic renal disease: a cross-sectional survey study. PLoS ONE 2015;10:e0126400.

11. Duplaga M. The acceptance of e-health solutions among patients with chronic respiratory conditions. Telemed J E Health 2013;19:683-91.

\begin{tabular}{|c|c|c|c|}
\hline Symptom & $\begin{array}{l}\text { Online group } \\
(n=156), n(\%)\end{array}$ & $\begin{array}{l}\text { Control group } \\
(n=148), n(\%)\end{array}$ & $P$ value $^{\ddagger}$ \\
\hline \multicolumn{4}{|l|}{ Abdominal pain } \\
\hline No & $71(45.5)$ & $107(72.3)$ & \multirow[t]{4}{*}{$<.001$} \\
\hline Incidentally* & 72 (46.2) & $38(25.7)$ & \\
\hline Frequent* & $13(8.3)$ & $2(1.4)$ & \\
\hline Unknown & $0(.0)$ & $1(0.7)$ & \\
\hline \multicolumn{4}{|l|}{ Appetite } \\
\hline Decreased & $10(6.4)$ & $5(3.4)$ & \multirow[t]{4}{*}{.036} \\
\hline Normal & $123(78.8)$ & 135 (91.2) & \\
\hline Increased & $23(14.7)$ & $4(2.7)$ & \\
\hline Unknown & $0(.0)$ & $4(2.7)$ & \\
\hline \multicolumn{4}{|l|}{ Lassitude } \\
\hline No & $90(57.7)$ & $123(83.1)$ & \multirow[t]{4}{*}{$<.001$} \\
\hline Incidentally & 45 (28.8) & $9(6.1)$ & \\
\hline Frequent & 18 (11.5) & $4(2.7)$ & \\
\hline Unknown & $3(1.9)$ & $12(8.1)$ & \\
\hline \multicolumn{4}{|l|}{ Defecation } \\
\hline Constipation ${ }^{\dagger}$ & $13(8.3)$ & $9(6.1)$ & \multirow[t]{4}{*}{.943} \\
\hline Normal & $134(85.9)$ & $132(89.2)$ & \\
\hline Diarrhea $^{\dagger}$ & $7(4.5)$ & $3(2.0)$ & \\
\hline Unknown & $2(1.3)$ & $4(2.7)$ & \\
\hline
\end{tabular}

*Incidentally = once a week or less; frequent $=$ multiple times per week.

†Constipation $=\leq 3$ stools per week; diarrhea $=\geq 3$ stools per day.

fUsing Armitage's trend test, omitting "unknown" as an answer. 
Table IV. Satisfaction of 304 participants with CD with either the online or outpatient consultation (controls) assessed at time of the online or outpatient consultation

\begin{tabular}{|c|c|c|c|c|c|c|c|c|}
\hline \multirow[b]{2}{*}{$\begin{array}{l}\text { Questions at time of online or } \\
\text { outpatient consultation (baseline) }\end{array}$} & \multirow[b]{2}{*}{$\begin{array}{l}\text { Study } \\
\text { arms }\end{array}$} & \multicolumn{5}{|c|}{ Answer options } & \multirow[b]{2}{*}{$\boldsymbol{P}^{\dagger}$} & \multirow[b]{2}{*}{$\begin{array}{l}\text { Original } \\
\text { item and } \\
\text { source }\end{array}$} \\
\hline & & $\begin{array}{l}\text { Strongly } \\
\text { disagree, } \\
\text { n (\%) }\end{array}$ & $\begin{array}{l}\text { Disagree, } \\
\text { n (\%) }\end{array}$ & $\begin{array}{l}\text { Uncertain, } \\
\text { n (\%) }\end{array}$ & $\begin{array}{l}\text { Agree, } \\
\text { n (\%) }\end{array}$ & $\begin{array}{l}\text { Strongly } \\
\text { agree, } \\
\mathrm{n}(\%)\end{array}$ & & \\
\hline \multirow{2}{*}{$\begin{array}{l}\text { The consultation needs to be more } \\
\text { thorough concerning my (child's) } \\
\text { treatment and examination. }{ }^{*}\end{array}$} & Online & $71(45.8)$ & $22(14.2)$ & $36(23.2)$ & $22(14.2)$ & $4(2.6)$ & \multirow[t]{2}{*}{.547} & \multirow{2}{*}{$\begin{array}{l}\text { Doctors need to be more thorough in } \\
\text { treating and examining me (PSQ-III/ } \\
\text { TECH). }\end{array}$} \\
\hline & Control & $68(45.9)$ & $23(15.5)$ & $42(28.4)$ & $11(7.4)$ & $4(2.7)$ & & \\
\hline \multirow{2}{*}{$\begin{array}{l}\text { I am very satisfied with the } \\
\text { consultation. }\end{array}$} & Online & $3(1.9)$ & $10(6.4)$ & $19(12.2)$ & $48(30.8)$ & $76(48.7)$ & \multirow[t]{2}{*}{.032} & \multirow{2}{*}{$\begin{array}{l}\text { I am very satisfied with the medical care I } \\
\text { receive (PSQ-III/GSAT). }\end{array}$} \\
\hline & Control & $0(0)$ & $4(2.7)$ & 18 (12.2) & $40(27.0)$ & $86(58.1)$ & & \\
\hline \multirow{2}{*}{$\begin{array}{l}\text { The reasons for medical tests are clear } \\
\text { to me. }\end{array}$} & Online & $1(0.6)$ & $1(0.6)$ & $2(1.3)$ & $31(19.9)$ & $121(77.6)$ & \multirow[t]{2}{*}{.321} & \multirow{4}{*}{$\begin{array}{l}\text { Doctors are good about explaining the } \\
\text { reason for medical tests (PSQ-III/COMM). } \\
\text { I think my doctor's office has everything } \\
\text { needed to provide complete medical care } \\
\text { (PSQ-III/TECH). }\end{array}$} \\
\hline & Control & $1(0.7)$ & $4(2.7)$ & $5(3.4)$ & $25(16.9)$ & $113(76.4)$ & & \\
\hline \multirow{2}{*}{$\begin{array}{l}\text { I think that everything needed to } \\
\text { provide complete medical care is } \\
\text { available during the consultation. }\end{array}$} & Online & $13(8.3)$ & $15(9.6)$ & $22(14.1)$ & $38(24.4)$ & $68(43.6)$ & \multirow[t]{2}{*}{$<.001$} & \\
\hline & Control & $1(0.7)$ & $2(1.4)$ & $13(8.8)$ & $26(17.6)$ & $106(71.6)$ & & \\
\hline \multirow{2}{*}{$\begin{array}{l}\text { The doctor can get a good } \\
\text { understanding of my (child's) } \\
\text { medical problem. }\end{array}$} & Online & $5(3.2)$ & $14(9.0)$ & $20(12.8)$ & $52(33.3)$ & $65(41.7)$ & \multirow[t]{2}{*}{.001} & \multirow{2}{*}{$\begin{array}{l}\text { A nurse can get a good understanding } \\
\text { of my medical problem during a video } \\
\text { visit (TSUQ). }\end{array}$} \\
\hline & Control & $2(1.4)$ & $4(2.7)$ & $17(11.5)$ & $33(22.3)$ & $92(62.2)$ & & \\
\hline \multirow{2}{*}{$\begin{array}{l}\text { During the consultation, I am always } \\
\text { allowed to say everything that I think } \\
\text { is important.* }\end{array}$} & Online & $6(3.9)$ & $14(9.0)$ & $11(7.1)$ & $46(29.7)$ & $78(50.3)$ & \multirow[t]{2}{*}{$<.001$} & \multirow{2}{*}{$\begin{array}{l}\text { During my medical visits, I am always } \\
\text { allowed to say everything that I think is } \\
\text { important (PSQ-III/COMM). }\end{array}$} \\
\hline & Control & $1(0.7)$ & $1(0.7)$ & $8(5.4)$ & $24(16.2)$ & $114(77.0)$ & & \\
\hline \multirow{2}{*}{$\begin{array}{l}\text { It's hard for me/my child to get medical } \\
\text { care on short notice. }\end{array}$} & Online & $89(57.4)$ & $22(14.2)$ & $33(21.3)$ & $6(3.9)$ & $5(3.2)$ & \multirow[t]{2}{*}{.250} & It's hard for me to get medical care on short \\
\hline & Control & $74(50)$ & $22(14.9)$ & $41(27.7)$ & $6(4.1)$ & $5(3.4)$ & & notice (PSQ-III/AAC). \\
\hline Sometimes during the consultation, & Online & $112(72.3)$ & 27 (17.4) & $9(5.8)$ & $6(3.9)$ & $1(0.6)$ & 167 & Sometimes doctors use medical terms \\
\hline $\begin{array}{l}\text { medical terms are used that I don't } \\
\text { understand.. }\end{array}$ & Control & $102(68.9)$ & $24(16.2)$ & $8(5.4)$ & $10(6.8)$ & $4(2.7)$ & & $\begin{array}{l}\text { without explaining what they mean } \\
\text { (PSQ-III/COMM). }\end{array}$ \\
\hline The consultation hours are convenient & Online & $3(1.9)$ & $7(4.5)$ & $18(11.6)$ & $24(15.5)$ & $103(66.5)$ & .018 & The office hours when I can get medical \\
\hline (good) for me.* & Control & $7(4.7)$ & $9(6.1)$ & $26(17.6)$ & $26(17.6)$ & $80(54.1)$ & & $\begin{array}{l}\text { care are convenient (good) for me } \\
\text { (PSQ-III/AAC). }\end{array}$ \\
\hline I feel foolish during the consultation.* & Online & $131(84.5)$ & $9(5.8)$ & $7(4.5)$ & $3(1.9)$ & $5(3.2)$ & .463 & Sometimes doctors make me feel foolish \\
\hline & Control & $128(86.5)$ & $11(7.4)$ & $2(1.4)$ & $4(2.7)$ & $3(2.0)$ & & (PSQ-III/INTER). \\
\hline The consultation is too business-like & Online & $95(61.3)$ & $22(14.2)$ & $17(11.0)$ & $13(8.4)$ & $8(5.2)$ & $<.001$ & Doctors are too business-like and \\
\hline and impersonal.** & Control & 107 (72.3) & $28(18.9)$ & $10(6.8)$ & $2(1.4)$ & $1(0.7)$ & & impersonal toward me (PSQ-III/INTER). \\
\hline I am involved in my (child's) & Online & $2(1.3)$ & $0(.0)$ & $1(0.6)$ & $15(9.7)$ & 137 (88.4) & .223 & NA \\
\hline medical care.* & Control & $2(1.4)$ & $2(1.4)$ & $5(3.4)$ & $13(8.8)$ & $126(85.1)$ & & \\
\hline There are some things about the & Online & $49(31.60$ & $26(16.8)$ & $43(27.7)$ & $19(12.3)^{\ddagger}$ & $18(11.6)^{\ddagger}$ & $<.001$ & There are some things about the medical \\
\hline $\begin{array}{l}\text { consultation I receive that could } \\
\text { be better.* }\end{array}$ & Control & $71(48.0)$ & $30(20.3)$ & $31(20.9)$ & $11(7.4)^{\ddagger}$ & $5(3.4)^{\ddagger}$ & & $\begin{array}{l}\text { care I receive that could be better (PSQ- } \\
\text { III/GSAT). }\end{array}$ \\
\hline The time allotted for a consultation is & Online & $82(52.9)$ & $25(16.1)$ & $32(20.6)$ & $11(7.1)$ & $5(3.2)$ & .480 & Those who provide my medical care \\
\hline not efficient.* & Control & $84(56.8)$ & $24(16.2)$ & $27(18.2)$ & $8(5.4)$ & & & $\begin{array}{l}\text { sometimes hurry too much when they } \\
\text { treat me (PSQ-III/TIME). }\end{array}$ \\
\hline The place where I can get the & Online & $4(2.6)$ & $6(3.9)$ & $11(7.1)$ & $23(14.8)$ & $111(71.9)$ & .001 & Places where I can get medical care are \\
\hline $\begin{array}{l}\text { consultation is very conveniently } \\
\text { located.* }\end{array}$ & Control & $8(5.4)$ & $11(7.4)$ & $26(17.6)$ & $24(16.2)$ & $79(53.4)$ & & very conveniently located (PSQ-III/AAC). \\
\hline When I/my child receives medical care, & Online & $93(60.0)$ & $10(6.5)$ & $16(10.3)$ & $6(3.9)$ & $30(19.4)$ & .097 & When I am receiving medical care, they \\
\hline $\begin{array}{l}\text { they should pay more attention to my } \\
\text { (child's) privacy.* }\end{array}$ & Control & $102(68.9)$ & $13(8.8)$ & $7(4.7)$ & $3(2.0)$ & $23(15.5)$ & & $\begin{array}{l}\text { should pay more attention to my privacy } \\
\text { (PSQ-III/NTER). }\end{array}$ \\
\hline If I have a medical question, I can reach & Online & $9(5.8)$ & $9(5.8)$ & $41(26.5)$ & $25(16.1)$ & $71(45.8)$ & 218 & If I have a medical question, I can reach a \\
\hline $\begin{array}{l}\text { a doctor for help without any } \\
\text { problem.* }^{*}\end{array}$ & Control & $4(2.7)$ & $9(6.1)$ & $33(22.3)$ & $29(19.6)$ & 73 (49.3) & & $\begin{array}{l}\text { doctor without any problem (PSQ-III/ } \\
\text { AAC). }\end{array}$ \\
\hline All things considered, the consultation I & Online & $5(3.2)$ & $5(3.2)$ & $24(15.5)$ & $62(40.0)$ & $59(38.1)$ & $<.001$ & All things considered, the medical care I \\
\hline receive is excellent.* & Control & $1(0.7)$ & $1(0.7)$ & $13(8.8)$ & $47(31.8)$ & $86(58.1)$ & & receive is excellent (PSQ-III/GSAT). \\
\hline I think the time the consultation takes, & Online & $6(3.9)$ & $14(9.0)$ & $25(16.1)$ & $44(28.4)$ & $66(42.6)$ & .969 & Doctors usually spend plenty of time with \\
\hline $\begin{array}{l}\text { including blood tests and travel- and } \\
\text { waiting time if applicable, is good. }{ }^{*}\end{array}$ & Control & $8(5.4)$ & $11(7.4)$ & $25(16.9)$ & $37(25.0)$ & $67(45.3)$ & & me (PSQ-III/TIME). \\
\hline I am/my child is able to get medical & Online & $3(1.9)$ & $2(1.3)$ & $22(14.2)$ & $34(21.9)$ & $94(60.6)$ & .711 & I am able to get medical care whenever I \\
\hline care whenever $1 /$ my child need(s) it.* & Control & $2(1.4)$ & $3(2.0)$ & $19(12.8)$ & $31(20.9)$ & $93(62.8)$ & & need it (PSQ-III/AAC). \\
\hline
\end{tabular}

PSQ-III, Ware's Patient Satisfaction Questionnaire III, subscales of the PSQ-III; AAC, Access/availability/convenience; COMM, communication; GSAT, general satisfaction; INTER, interpersonal aspects; NA, not applicable; TECH, technical quality; TIME, time spent with doctor; TSUQ, Telemedicine Satisfaction and Usefulness Questionnaire. ${ }^{18}$

$P$ values $<0.05$ are presented in bold.

${ }^{*}$ One participant did not fill out the first question, and another participant did not fill out questions 6-20.

$\dagger \chi^{2}$ test for trend (linear-by-linear association).

fWhen asked what could be better, participants in online group answered: "more (multiple choice) answer options and more space for comments" ( $n=10)$; "questions and answers adjusted to age of participant" ( $n=6)$; "the (instructions of the) point of care test" $(n=5)$; "lack of a targeted and face-to-face conversation with doctor" $(n=4)$; "technical difficulties with accessing self-management system and/or too many routes for information (e-mail/post/web)" ( $n=3$ ); "lack of a physical examination" ( $n=3)$; "design of the questionnaires" ( $n=2)$; "when more children in one family are affected, answers to some questions are the same for each child" ( $n=1)$; "lack of a combined assessment of physical health and mental development" ( $n=1)$; "lack of blood tests for e.g. iron deficiency" ( $n=1$ ); and "include a homevisit" $(n=1)$. In the outpatient group, patients answered: "time with doctor is too short or time in waiting room is longer than time with doctor" ( $n=3$ ); "more attention for healthy diet and testing in blood of nutrition status" ( $n=2)$; "better to have blood withdrawn before consultation with doctor so that results can be discussed during the consultation" ( $n=2)$; "lack of time with doctor without child in the room" ( $n=1$ ); "more attention for the patient's functioning in daily life with celiac disease" $(n=1)$; "standard annual consultation with the dietician and checking of blood twice a year" ( $\mathrm{n}=1)$; "annual check-ups are not necessary" ( $n=1)$; and "blood withdrawal is traumatic for my child" $(n=1)$. 
Table V. Satisfaction of 304 participants with CD with either the online or outpatient consultation (controls), assessed approximately 6 months after the online or outpatient consultation

\begin{tabular}{|c|c|c|c|c|c|c|c|c|}
\hline \multirow[b]{2}{*}{$\begin{array}{l}\text { Questions approximately } 6 \text { months } \\
\text { after online or outpatient } \\
\text { consultation }\end{array}$} & \multirow[b]{2}{*}{$\begin{array}{l}\text { Study } \\
\text { arm }\end{array}$} & \multicolumn{5}{|c|}{ Answer options } & \multirow[b]{2}{*}{$P^{*}$} & \multirow[b]{2}{*}{ Original item and source } \\
\hline & & $\begin{array}{l}\text { Strongly } \\
\text { disagree, } \\
\text { n (\%) }\end{array}$ & $\begin{array}{l}\text { Disagree, } \\
\text { n (\%) }\end{array}$ & $\begin{array}{l}\text { Uncertain, } \\
\text { n (\%) }\end{array}$ & $\begin{array}{l}\text { Agree, } \\
\text { n (\%) }\end{array}$ & $\begin{array}{l}\text { Strongly } \\
\text { agree, } \\
\text { n (\%) }\end{array}$ & & \\
\hline I am very satisfied with the consultation. & $\begin{array}{l}\text { Online } \\
\text { Control }\end{array}$ & $\begin{array}{l}4(2.6) \\
0(.0)\end{array}$ & $\begin{array}{l}8(5.1) \\
4(2.7)\end{array}$ & $\begin{array}{l}22(14.1) \\
16(10.8)\end{array}$ & $\begin{array}{l}44(28.2) \\
27(18.2)\end{array}$ & $\begin{array}{r}78(50.0) \\
101(68.2)\end{array}$ & .001 & $\begin{array}{l}\text { I am very satisfied with the medical care } \\
\text { | receive (PSQ-III/GSAT). }\end{array}$ \\
\hline $\begin{array}{l}\text { It's hard for me/my child to get medical } \\
\text { care on short notice. }\end{array}$ & $\begin{array}{l}\text { Online } \\
\text { Control }\end{array}$ & $\begin{array}{l}88(56.4) \\
81(54.7)\end{array}$ & $\begin{array}{l}32(20.5) \\
21(14.2)\end{array}$ & $\begin{array}{l}27(17.3) \\
36(24.3)\end{array}$ & $\begin{array}{l}7(4.5) \\
4(2.7)\end{array}$ & $\begin{array}{l}2(1.3) \\
6(4.1)\end{array}$ & .266 & $\begin{array}{l}\text { It's hard for me to get medical care on } \\
\text { short notice (PSQ-III/AAC). }\end{array}$ \\
\hline $\begin{array}{l}\text { I could understand the doctor's } \\
\text { recommendations. }\end{array}$ & $\begin{array}{l}\text { Online } \\
\text { Control }\end{array}$ & $\begin{array}{l}2(1.3) \\
0(.0)\end{array}$ & $\begin{array}{l}1(0.6) \\
2(1.4)\end{array}$ & $\begin{aligned} 17 & (10.9) \\
8 & (5.4)\end{aligned}$ & $\begin{array}{l}18(11.5) \\
11(7.5)\end{array}$ & $\begin{array}{l}118(75.6) \\
126(85.7)\end{array}$ & .031 & $\begin{array}{l}\text { I could understand the specialist's } \\
\text { recommendations (PSS). }\end{array}$ \\
\hline $\begin{array}{l}\text { I am involved in my (child's) medical } \\
\text { care. }\end{array}$ & $\begin{array}{l}\text { Online } \\
\text { Control }\end{array}$ & $\begin{array}{l}2(1.3) \\
2(1.4)\end{array}$ & $\begin{array}{l}2(1.3) \\
6(4.1)\end{array}$ & $\begin{array}{l}0(.0) \\
0(.0)\end{array}$ & $\begin{array}{c}16(10.3) \\
7(4.7)\end{array}$ & $\begin{array}{l}136(87.2) \\
133(89.9)\end{array}$ & .970 & NA \\
\hline $\begin{array}{l}\text { There are some things about the } \\
\text { consultation I receive that could be } \\
\text { better. }\end{array}$ & $\begin{array}{l}\text { Online } \\
\text { Control }\end{array}$ & $\begin{array}{l}43(27.6) \\
59(39.9)\end{array}$ & $\begin{array}{l}34(21.8) \\
23(15.5)\end{array}$ & $\begin{array}{l}50(32.1) \\
42(28.4)\end{array}$ & $\begin{array}{l}11(7.1)^{\dagger} \\
11(7.4)^{\dagger}\end{array}$ & $\begin{array}{l}18(11.5)^{\dagger} \\
13(8.8)^{\dagger}\end{array}$ & .114 & $\begin{array}{l}\text { There are some things about the } \\
\text { medical care I receive that could be } \\
\text { better (PSQ-III/GSAT). }\end{array}$ \\
\hline $\begin{array}{l}\text { Doctors always respond to what I tell } \\
\text { them. }\end{array}$ & $\begin{array}{l}\text { Online } \\
\text { Control }\end{array}$ & $\begin{array}{l}3(1.9) \\
1(0.7)\end{array}$ & $\begin{array}{l}5(3.2) \\
2(1.4)\end{array}$ & $\begin{array}{l}27(17.3) \\
22(15.0)\end{array}$ & $\begin{array}{l}33(21.2) \\
19(12.9)\end{array}$ & $\begin{array}{r}88(56.4) \\
103(70.1)\end{array}$ & .028 & $\begin{array}{l}\text { Doctors sometimes ignore what I tell } \\
\text { them (PSQ-III/COMM). }\end{array}$ \\
\hline $\begin{array}{l}\text { If I have a medical question, I can reach } \\
\text { a doctor for help without any } \\
\text { problem. }\end{array}$ & $\begin{array}{l}\text { Online } \\
\text { Control }\end{array}$ & $\begin{array}{l}2(1.3) \\
1(0.7)\end{array}$ & $\begin{array}{l}3(1.9) \\
8(5.4)\end{array}$ & $\begin{array}{l}35(22.4) \\
39(26.4)\end{array}$ & $\begin{array}{l}28(17.9) \\
31(20.9)\end{array}$ & $\begin{array}{l}88(56.4) \\
69(46.6)\end{array}$ & .095 & $\begin{array}{l}\text { If I have a medical question, I can reach } \\
\text { a doctor without any problem } \\
\text { (PSQ-III/AAC). }\end{array}$ \\
\hline $\begin{array}{l}\text { All things considered, the consultation I } \\
\text { receive is excellent. }\end{array}$ & $\begin{array}{l}\text { Online } \\
\text { Control }\end{array}$ & $\begin{array}{l}4(2.6) \\
0(.0)\end{array}$ & $\begin{array}{l}8(5.1) \\
4(2.7)\end{array}$ & $\begin{array}{l}18(11.5) \\
18(12.2)\end{array}$ & $\begin{array}{l}62(39.7) \\
47(31.8)\end{array}$ & $\begin{array}{l}64(41.0) \\
79(53.4)\end{array}$ & .019 & $\begin{array}{l}\text { All things considered, the medical care I } \\
\text { receive is excellent (PSQ-III/GSAT). }\end{array}$ \\
\hline $\begin{array}{l}\text { I am/my child is able to get medical care } \\
\text { whenever I/my child need(s) it. }\end{array}$ & $\begin{array}{l}\text { Online } \\
\text { Control }\end{array}$ & $\begin{array}{l}3(1.9) \\
4(2.7)\end{array}$ & $\begin{array}{l}19(12.2) \\
24(16.2)\end{array}$ & $\begin{array}{l}0(.0) \\
0(.0)\end{array}$ & $\begin{array}{l}37(23.7) \\
30(20.3)\end{array}$ & $\begin{array}{r}97(62.2) \\
90(60.8)\end{array}$ & .458 & $\begin{array}{l}\text { I am able to get medical care whenever } \\
\text { I need it (PSQ-III/AAC). }\end{array}$ \\
\hline $\begin{array}{l}\text { The online consultation was as good as } \\
\text { a regular outpatient consultation }\end{array}$ & Online & $20(12.8)$ & $27(17.3)$ & $34(21.8)$ & $35(22.4)$ & $40(25.6)$ & NA & $\begin{array}{l}\text { The telemedicine visit was as good as a } \\
\text { regular in-person visit (PSS). }\end{array}$ \\
\hline $\begin{array}{l}\text { I would be willing to have an online } \\
\text { consultation again in the future } \\
\text { (for my child). }\end{array}$ & Online & $21(13.5)$ & $11(7.1)$ & $34(21.8)$ & $28(17.9)$ & $62(39.7)$ & NA & $\begin{array}{l}\text { I would be willing to have my child see a } \\
\text { specialist using telemedicine again in } \\
\text { the future (PSS). }\end{array}$ \\
\hline $\begin{array}{l}\text { There were technical difficulties with } \\
\text { the online consultation. }\end{array}$ & Online & $80(51.3)$ & $11(7.1)$ & $17(10.9)$ & $17(10.9)$ & $31(19.9)$ & NA & $\begin{array}{l}\text { Were there any technical difficulties } \\
\text { with the TM equipment during your } \\
\text { consultation (Dick)? }\end{array}$ \\
\hline $\begin{array}{l}\text { I prefer to travel to have a consultation } \\
\text { with the doctor in person. }\end{array}$ & Online & $34(21.8)$ & $27(17.3)$ & $31(19.9)$ & $34(21.8)$ & $30(19.2)$ & NA & $\begin{array}{l}\text { Would you have preferred to have } \\
\text { travelled to have had this } \\
\text { consultation in person with your } \\
\text { specialist (Dick)? }\end{array}$ \\
\hline
\end{tabular}

PSQ-III, Ware's Patient Satisfaction Questionnaire III, subscales of the PSQ-III; AAC, Access/availability/convenience; COMM, communication; GSAT, general satisfaction; INTER, interpersonal aspects; $N A$, not applicable; $P S S$, Parent Satisfaction Survey ${ }^{20} ; T E C H$, technical quality; TIME, time spent with doctor; TSUQ, Telemedicine Satisfaction and Usefulness Questionnaire. ${ }^{18}$

$P$ values $<0.05$ are presented in bold.

${ }^{*} \chi^{2}$ test for trend (linear-by-linear association).

†When asked what could be better, participants in online group answered: "technical difficulties with accessing self-management system and/or too many routes for information (e-mail/post/ web)" ( $(n=8)$; "the (instructions of the) point of care test" $(n=6)$; "lack of a targeted and face-to-face conversation with doctor" ( $n=5)$; "lack of blood tests for e.g. iron deficiency" ( $n=2)$; "time to feedback after consultation was too long " $(n=2)$; "questions are unclear and sometimes more or less repetitive" $(n=1)$; "questions are made for young children" ( $n=1)$; "have more attention for the child" ( $n=1)$; and "package with point of care test was damaged when delivered" $(n=1)$. In the outpatient group, patients answered: "doctor doesn't have the answer to questions concerning certain blood results $(n=1)$, nutrition $(n=1)$, stool problems $(n=1)$ "; "waiting time is too long" $(n=2)$; "focus communication on the child" ( $n=2)$; "fear of needles or dislike to go have blood withdrawn before consultation with doctor on a separate day" $(\mathrm{n}=2)$; "time with doctor is too short or possibly better to have bi-annual (longer) check-ups" ( $\mathrm{n}=2)$; "travel distance is long" $(n=1)$; "consultation is very non-committal" $(n=1)$; "show more understanding" $(n=1)$; "time to feedback after consultation was too long " $(n=1)$; "consultation was chaotic" $(n=1)$; "need more guidance" $(n=1)$; and "prefer point of care test over hospital visit" $(n=1)$. 
Table VI. Participants' experience with the point-of care (POC) self-test ${ }^{*}$

\begin{tabular}{|c|c|c|c|}
\hline \multirow[b]{2}{*}{ Question } & \multirow{2}{*}{$\begin{array}{l}\text { At time of the online } \\
\text { consultation } \\
n=153^{\dagger}(\%)\end{array}$} & \multicolumn{2}{|c|}{ (approximately 6 months later) } \\
\hline & & $\begin{array}{l}\text { Online group } \\
\mathbf{n}=\mathbf{1 4 8}^{\dagger}(\%)\end{array}$ & $\begin{array}{c}\text { Control group, } \\
n=133^{\dagger}(\%)\end{array}$ \\
\hline \multicolumn{4}{|c|}{ Were the instructions clear? } \\
\hline Yes & $144(94.1)$ & $144(97.3)$ & $124(93.2)$ \\
\hline No & $9(5.9)$ & $4(2.7)$ & $9(6.8)$ \\
\hline \multicolumn{4}{|c|}{ Was the test difficult to perform? } \\
\hline Yes & $21(13.7)$ & $12(8.1)$ & 18 (13.5) \\
\hline No & $132(86.3)$ & $136(91.1)$ & $115(86.5)$ \\
\hline \multicolumn{4}{|c|}{ Was your child (or were you) scared? } \\
\hline Yes & $77(50.3)$ & $61(41.2)$ & $60(45.1)$ \\
\hline No & 76 (49.7) & 87 (58.8) & $73(54.9)$ \\
\hline \multicolumn{4}{|c|}{ Was the person performing the puncture scared? } \\
\hline Yes & $7(4.6)$ & $4(2.7)$ & $3(2.3)$ \\
\hline No & $146(95.4)$ & $144(97.3)$ & $130(97.7)$ \\
\hline \multicolumn{4}{|c|}{ Was puncture more painful than traditional venipuncture? } \\
\hline Yes & $22(14.4)$ & $13(8.8)$ & $12(9.8)$ \\
\hline No & $131(85.6)$ & $135(91.2)$ & $120(90.2)$ \\
\hline \multicolumn{4}{|c|}{ Was the procedure after the puncture clear? } \\
\hline Yes & $149(97.4)$ & $140(94.6)$ & $130(97.7)$ \\
\hline No & $4(2.6)$ & $8(5.4)$ & $3(2.3)$ \\
\hline \multicolumn{4}{|c|}{ Was the result clear? } \\
\hline Yes & $153(100)$ & $148(100)$ & $133(100)$ \\
\hline No & 0 & 0 & 0 \\
\hline \multicolumn{4}{|c|}{ Do you prefer the traditional venipuncture? } \\
\hline Yes & $28(18.3)^{\ddagger}$ & $30(20.3)^{\ddagger}$ & $25(18.8)^{\ddagger}$ \\
\hline No & $125(81.7)$ & 118 (79.7) & 106 (81.2) \\
\hline
\end{tabular}

*The participants randomized to the online group had performed the POC self-test twice in a period of approximately 6 months, and the controls had performed it once.

†The POC self-test failed for 3 of 156 online participants at time of the online consultation and for 8 of 146 online participants and 14 of 148 controls at the time of follow-up. One control participant with a negative POC self-test did not answer the questions.

†Missing additional blood tests for iron and vitamins, and so on $(n=34)$; prefer hospital environment and/or nurse to perform the puncture $(n=20)$; finger puncture more painful or scary than venipuncture $(n=13)$; less reassured by negative self-test than by conventional test $(n=12)$; and conventional test is easier $(n=4)$.

Table VII. Mean costs per participant (price level 2015)

\begin{tabular}{|c|c|c|c|c|}
\hline \multirow[b]{2}{*}{ Cost categories } & \multicolumn{2}{|c|}{$\begin{array}{l}\text { Mean costs during } \\
\text { the study period }\end{array}$} & \multirow[b]{2}{*}{$P^{*}$} & \multirow[b]{2}{*}{ Difference } \\
\hline & $\begin{array}{l}\text { Online group } \\
(\mathrm{n}=156)\end{array}$ & $\begin{array}{l}\text { Control group } \\
(n=148)\end{array}$ & & \\
\hline \multicolumn{5}{|l|}{ Medical costs } \\
\hline Staff costs physician & $€ 51$ & $€ 65$ & NA & $€-14$ \\
\hline $\lg A$ TG2A & $€ 6$ & $€ 15$ & NA & $€-9$ \\
\hline $\begin{array}{l}\text { Extra follow-up consultations after baseline consultation until } \\
\text { reassessment, mean (SD) }\end{array}$ & $€ 33(60)$ & $€ 42(86)$ & .28 & $€-9$ \\
\hline $\begin{array}{l}\text { Extra follow-up blood work after baseline consultation until } \\
\text { reassessment, mean (SD) }\end{array}$ & $€ 40(90)$ & $€ 37(88)$ & .37 & $€ 3$ \\
\hline Subtotal medical costs, mean (SD) & $€ 130$ (144) & $€ 159$ (162) & .096 & $€-29$ \\
\hline \multicolumn{5}{|l|}{ Nonmedical costs } \\
\hline Travel to consultation and back, mean (SD) & NA & $€ 14$ (19) & NA & $€-14$ \\
\hline Duration of consultation for participant or parent, mean (SD) & $€ 13(10)$ & $€ 63(68)$ & $<.001$ & $€-50$ \\
\hline Subtotal nonmedical costs, mean (SD) & $€ 13(10)$ & $€ 77(80)$ & $<.001$ & $€-64$ \\
\hline Total, mean (SD) & $€ 143(144)$ & $€ 236$ (189) & $<.001$ & $€-93$ \\
\hline
\end{tabular}

NA, Not applicable.

Details underlying calculation of unit costs including overhead and utility costs in Euros: Staff costs physician: €163.12 per hour (including housing and overhead costs). Mean duration consultation: outpatient 0.40 hours (range, $0.15-0.78$ ), online 0.31 hours (range, 0.10-1.22). Point of care test for lgA transglutaminase type 2 antibodies (TG2A) €3.50 per unit; preparation $€ 2.22$ per unit (based on 5 min of work per test for a medical secretary); and sending $€ 0.43$ per unit. Follow-up consultations (physician's or patient/parent's initiative) after the outpatient or online consultation and before the end of participating ( 6 months) were considered, and included consultations with the physician (outpatient or telephonic), dietician, psychologist/pedagogue, or endocrinologist for problems related to growth or thyroid function. Follow-up blood work (physician's or patient/parent's initiative) after the outpatient or online consultation and before the end of participating ( $\sim 6$ months) was considered if related to follow-up for CD. The mean travel distance to the outpatient consultation and back was $26.72 \mathrm{~km}$ (range, 0 -320). Costs per km were: by car, $€ 0.22$ plus $€ 3.33$ for parking costs $(n=104)$; by public transport, $€ 0.22(n=15)$. Costs in case leave from work was taken in control group ( $n=53$, mean hours: 3.96 range, $1-12$ [both parents took a day off]), $€ 32.41$ per hour. Otherwise in the control group ( $n=95$; mean hours, 1.87 ; range, 0.17-6.0) and in the entire online group (mean hours, 0.95 ; range, $0.17-8.00$ [experienced technical problems]), €13.87 per hour.

*Using generalized estimating equations. 
Table VIII. Comparison of the results of the 3 POC tests

\begin{tabular}{|c|c|c|c|c|c|c|c|}
\hline \multirow[b]{2}{*}{ POC test } & \multicolumn{2}{|c|}{$\begin{array}{c}\text { TG2A in conventional } \\
\text { laboratory }\end{array}$} & \multirow[b]{2}{*}{ Total } & \multirow[b]{2}{*}{$\begin{array}{l}\text { Sensitivity* } \\
\text { (95\% Cl) }\end{array}$} & \multirow[b]{2}{*}{$\begin{array}{l}\text { Specificity* } \\
\text { (95\% CI) }\end{array}$} & \multirow[b]{2}{*}{$\begin{array}{l}\text { Positive predictive } \\
\text { value }(95 \% \mathrm{Cl})\end{array}$} & \multirow[b]{2}{*}{$\begin{array}{l}\text { Negative predictive } \\
\text { value }(95 \% \mathrm{Cl})\end{array}$} \\
\hline & $\begin{array}{l}\text { Positive } \\
(n=47)\end{array}$ & $\begin{array}{l}\text { Negative } \\
(\mathrm{n}=95)\end{array}$ & & & & & \\
\hline \multicolumn{8}{|l|}{ Test A } \\
\hline \multicolumn{8}{|l|}{$10 \mathrm{~min}$} \\
\hline Positive & 16 & 1 & 17 & $0.34(0.20-0.48)$ & $0.99(0.97-1.0)$ & $0.94(0.83-1.00)$ & $0.75(0.68-0.83)$ \\
\hline Uninterpretable & 0 & 0 & 0 & & & & \\
\hline Negative & 31 & 94 & 125 & & & & \\
\hline \multicolumn{8}{|l|}{$30 \mathrm{~min}$} \\
\hline Positive & 29 & 3 & 32 & $0.62(0.48-0.76)$ & $0.97(0.93-1.0)$ & $0.91(0.81-1.00)$ & $0.84(0.77-0.91)$ \\
\hline Uninterpretable & 0 & 0 & 0 & & & & \\
\hline Negative & 18 & 92 & 110 & & & & \\
\hline \multicolumn{8}{|l|}{1 day } \\
\hline Positive & 28 & 0 & 28 & $0.60(0.46-0.74)$ & 1.00 & 1.00 & $0.83(0.76-0.90)$ \\
\hline Uninterpretable & 0 & 0 & 0 & & & & \\
\hline Negative & 19 & 95 & 114 & & & & \\
\hline \multicolumn{8}{|l|}{ Test B } \\
\hline \multicolumn{8}{|l|}{$10 \mathrm{~min}$} \\
\hline Positive & 42 & 7 & 49 & $\mathrm{~A}: 0.89(0.81-0.98)$ & A: $0.92(0.83-0.96)$ & $0.86(0.76-0.96)$ & $0.94(0.90-0.99)$ \\
\hline Uninterpretable & 0 & 3 & 3 & B: $0.89(0.81-0.98)$ & B: $0.92(0.87-0.98)$ & & \\
\hline Negative & 5 & 85 & 90 & & & & \\
\hline \multicolumn{8}{|l|}{$30 \mathrm{~min}$} \\
\hline Positive & 43 & 14 & 57 & A: 0.91 (0.84-0.99) & $\mathrm{A}: 0.80(0.72-0.88)$ & $0.75(0.64-0.87)$ & $0.97(0.94-1.00)$ \\
\hline Uninterpretable & 2 & 5 & 7 & B: $0.96(0.90-1.0)$ & B: $0.84(0.77-0.91)$ & & \\
\hline Negative & 2 & 76 & 78 & & & & \\
\hline \multicolumn{8}{|l|}{1 day } \\
\hline Positive & 45 & 19 & 64 & A: $0.96(0.90-1.0)$ & A: $0.74(0.65-0.83)$ & $0.70(0.59-0.82)$ & $0.99(0.96-1.00)$ \\
\hline Uninterpretable & 1 & 6 & 7 & B: $0.98(0.94-1.0)$ & B: $0.79(0.70-0.87)$ & & \\
\hline Negative & 1 & 70 & 71 & & & & \\
\hline \multicolumn{8}{|l|}{ Test C } \\
\hline \multicolumn{8}{|l|}{$10 \mathrm{~min}$} \\
\hline Positive & 26 & 18 & 44 & A: $0.55(0.41-0.70)$ & A: $0.56(0.46-0.66)$ & $0.59(0.44-0.74)$ & $0.76(0.66-0.86)$ \\
\hline Uninterpretable & 4 & 24 & 28 & B: $0.60(0.46-0.75)$ & B: $0.75(0.65-0.85)$ & & \\
\hline Negative & 17 & 53 & 70 & & & & \\
\hline \multicolumn{8}{|l|}{$30 \mathrm{~min}$} \\
\hline Positive & 33 & 33 & 66 & $\mathrm{~A}: 0.70(0.57-0.83)$ & A: 0.45 (0.35-0.55) & $0.50(0.38-0.62)$ & $0.80(0.69-0.90)$ \\
\hline Uninterpretable & 3 & 19 & 22 & B: 0.77 (0.64-0.89) & B: $0.57(0.45-0.68)$ & & \\
\hline Negative & 11 & 43 & 54 & & & & \\
\hline \multicolumn{8}{|l|}{1 day } \\
\hline Positive & 31 & 39 & 70 & A: $0.66(0.53-0.80)$ & A: $0.26(0.17-0.35)$ & $0.44(0.33-0.56)$ & $0.76(0.61-0.90)$ \\
\hline Uninterpretable & 8 & 31 & 39 & B: $0.79(0.67-0.92)$ & B: $0.39(0.27-0.51)$ & & \\
\hline Negative & 8 & 25 & 33 & & & & \\
\hline
\end{tabular}

*Sensitivity and specificity $(95 \% \mathrm{Cl})$ were calculated with or without taking the uninterpretable test results into account (A and B, respectively). 